\title{
An Investigation of Developments in Accounting Education in the United States During 1975-2017
}

\author{
Nas Ahadiat \\ California State Polytechnic University \\ Sepeedeh Ahadiat \\ California State Polytechnic University
}

\begin{abstract}
A 2008 report of the Advisory Committee on the Auditing Profession to the U.S. Department of the Treasury, argued that because of the disconnect between the academia and the profession, many new faculty have little or no practical accounting experience (Advisory Committee, 2008). Improving this relationship was considered beneficial to the development of college graduates who should be well-prepared for the entrylevel accounting positions. The committee later concluded that there are benefits in increasing participation of experienced faculty and suggested that business schools' accrediting agencies should maintain a policy that would support the idea that accounting faculty compose of both academically and professionally qualified faculty (Advisory Committee, 2008). A similar call was later made by the Pathways Commission in its recommendations for the future structure of higher education for the accounting profession (Pathways Commission, 2012, 27). The purpose of this study is to review the changes in accounting education in the United States over the years and the current make-up of the faculty.
\end{abstract}

Keyword: accounting, faculty, education, accreditation, practitioners, pathways commission

\section{INTRODUCTION}

Integrating accounting practice with education has been the subject of many discussion by both academicians and practitioners over the years (Albrecht and Sack, 2000; Advisory Committee, 2008; Pathways Commission, 2012). What is not quite clear is what is the optimum combination of academicians and practitioners in an accounting department for the preparation of competent and skillful graduates. To put this question differently, what is the proper mix of faculty (i.e., the mix of academicians and practitioners) for a well-functioning accounting department? In a 2008 report of the Advisory Committee on the Auditing Profession to the U.S. Department of the Treasury, it was contended that because of the disconnect between the academia and the profession, many new faculty have little or no practical accounting experience (Advisory Committee, 2008). Improving this relationship was considered beneficial to the development of well-prepared entry-level accounting professionals. The committee later concluded that there are benefits in increasing participation of faculty with professional experience and suggested that business schools' accrediting agencies should maintain a policy that would support the idea that accounting faculty compose of both academically and professionally qualified faculty (Advisory Committee, 2008). 
By further examination of this issue, in July 2012, the Pathways Commission outlined seven recommendations for the future structure of higher education for the accounting profession. The first of these recommendations addressed integration of accounting education with practice by stating that:

Build a learned profession for the future by purposeful integration of accounting research, education, and practice for students, accounting practitioners, and educators (Pathways Commission, 2012, 27).

The Commission believed that academic accounting research has little or no application to practice. Thus, in further addressing the need for an improved relationship between academia and practice, it outlines a set of objectives the first of which include:

Objective 1.1: Integrate professionally oriented faculty fully into significant aspects of accounting education, programs, and research (Pathways Commission, 2012, 30).

The following action plans were recommended for achieving the above objective:

- Include professionally oriented faculty as full and valued members of the accounting faculty.

- Identify, attract, and develop practitioners to become professionally oriented faculty.

This study is designed to investigate trends in the makeup of accounting faculty in the United States and the current mix of academicians with professionally oriented faculty.

\section{BACKGROUND}

The beginning of formal accounting education in the United States goes as far back as the late 1800s. Prior to this date accountants and auditors were trained in Europe and visited the United States for the purpose of auditing the operations of foreign businesses (Langenderfer, 1987). The first accounting course was offered at the University of Pennsylvania in 1883. This course was later called Theory of Accounting (Wyhe, 2007). The next major development in the history of accounting education was the emergence of the Certified Public Accountant (CPS) designation (Langenderfer, 1987). In 1896 New York State was the first state to pass a law for the establishment of the CPA license.

Soon after the establishment of the CPA designation, in 1900 New York University opened its school of business which included accounting instructions (Langenderfer, 1987). It did not take very long until many other universities added some courses to their curriculum for teaching accounting (by 1910, 52 universities had a course in accounting). During the next decade this number had more than doubled. Also, most universities established business schools with some offering accounting majors (Langenderfer, 1987). By 1926, 60 business schools across the nation had established a major in accounting.

Early accounting curriculums offered at the U.S. colleges and universities, were heavily influenced by the CPA exams. The curriculum included courses in accounting principles, cost accounting, and advanced accounting. Later, the income tax laws increased demand for two more practice-oriented courses, the taxation and auditing. During this period practitioners had great influence on what was taught in the accounting programs. The highest academic degree possessed by the accounting faculty teaching at the colleges and universities was a master's degree and a CPA certificate. This trend continued into the 1950s (Langenderfer, 1987).

By the passage of the Securities Acts of 1933 and 1934, the Securities and Exchange Commission took on the responsibilities to develop accounting principles and regulation for the accounting profession (Wyhe, 2007a). Events leading to the market crash and the newly established SEC gave both the academicians and practitioners the incentive to work together for the purpose of developing a set of generally accepted accounting principles. These developments provided a body of knowledge giving the accounting academicians greater identity and more respect in the academic community.

In the 1950s business schools across the country began to establish Master of Business Administration (MBA) degrees. The first of such program with accounting emphasis made its debut in 1955 (Langenderfer, 1987). The focus of these programs was to prepare students for the CPA exams. During this period many states started to require a university degree for taking the CPA examinations. 
In 1969 the Beamer Committee of the American Institute of Certified Public Accountants (AICPA) concluded that the CPAs need at least five years of college education to obtain the common body of knowledge that they need for their professional career (AICPA, 1969). Several years later, the Cohen Commission, another committee of the AICPA, noted that a graduate degree could immensely improve the quality and stature of students who wish to enter the accounting profession (AICPA, 1974).

In the 1970s relentless efforts of the AICPA and AAA resulted in the development of a set of educational standards for the accreditation of accounting programs. These standards helped to elevate the quality of accounting education to a level comparable to the other programs in social sciences (Wyhe, 2007b). This period is characterized by an explosive growth in the number graduate accounting programs. A survey of the accounting programs indicated that fifty-five graduate programs were added between 1975 and 1982 (Langenderfer, 1987). Perhaps, this event marks the beginning of the period when accounting education moved from a practitioner base to an academic base.

\section{STUDY QUESTION}

This study is designed to investigate the changes observed in the mix of faculty of the accounting programs in the United States' colleges and universities. Our examination will include an analysis of the change, if any, in the number of faculty by degree, certification, and rank. This analysis is intended to investigate whether the mix of accounting faculty has moved in the direction of the recommendations made by the Pathways Commission and other interested parties. Thus, the first hypothesis designed for this study is as follows:

H1: The faculty mix of the accounting programs has changed by hiring more professionally oriented faculty in response to the recommendations of the Pathways Commission by hiring more faculty with a master's degree.

Since professionally oriented faculty usually do not possess a doctorate degree, it is safe to assume that those who possess a master's degree with a certificate such as CPA have a practitioner orientation. Thus, for the purpose of testing the above hypothesis we will examine the relative change in the accounting faculty with master's degrees with those who possess a doctorate degree and the total change in the number of faculty from year to year.

The second hypothesis is as follows:

H2: The faculty mix of the accounting programs has changed by hiring more professionally oriented faculty in response to the recommendations of the Pathways Commission by hiring more faculty with certification.

The first hypothesis is further tested by examining trends in the number of faculty who possess one or more certification as an indicator of their professional orientation. While some of those who possess professional certifications may not be practicing accountants, because of the work experience required of the license application, it is safe to assume that faculty with certification have more practical experience that those without certifications (Butler, Gabriel, and Martin, 2002).

This study will further examine changes in the faculty's areas of teaching interests by looking at the subject areas taught over the years. In this study we will further investigate whether accounting programs have experienced any significant change in the makeup of their faculty who teach different accounting subjects over the past four decades.

\section{DATA COLLECTION}

The data required for this research were collected from the Hasselback Directories (2016). These directories include faculty information such as name, rank, and teaching areas for over 1,100 schools across the country. The first year for which such data were collected was 1974-75. In order to take a snap shot of 
accounting faculty information we analyzed the data presented in the directories every five years starting with the year 1975-76. This was the first year when a more complete set of data became available. The last period for which data are reported by these directories is 2016-17.

\section{THE RESULTS}

Table 1 reports the mix of faculty by degree over the past forty years. This table clearly shows that the number of faculty with doctorate degrees (i.e., Ph.D. and DBA) has continued to grow year after year. The same trend is experienced, while at a much slower pace, with respect to the faculty who possess a law degree. However, the number of faculty with master's degree has shown a continuous decline over the past thirty tears.

TABLE 1

TRENDS IN MIX OF ACCOUNTING FACULTY BY YEAR

\begin{tabular}{|c|c|c|c|c|c|c|}
\hline \multirow{2}{*}{$\begin{array}{c}\text { Academic } \\
\text { Years }\end{array}$} & \multicolumn{3}{|c|}{ Numbers } & \multicolumn{3}{c|}{ Percentages } \\
\cline { 2 - 7 } & Doctorate & Masters & JD \& Others & Doctorate & Masters & JD \& Others \\
\hline $1975-76$ & 1,162 & 384 & 64 & 72.2 & 23.8 & 4.0 \\
\hline $1980-81$ & 2,092 & 992 & 153 & 64.7 & 30.6 & 4.7 \\
\hline $1985-86$ & 3,031 & 1,194 & 163 & 69.1 & 27.2 & 3.7 \\
\hline $1990-91$ & 3,598 & 1,176 & 198 & 72.4 & 23.6 & 4.0 \\
\hline $1995-96$ & 4,309 & 1,069 & 204 & 77.2 & 19.2 & 3.6 \\
\hline $2000-01$ & 4,422 & 905 & 201 & 80.0 & 16.4 & 3.6 \\
\hline $2005-06$ & 4,602 & 866 & 225 & 80.8 & 15.2 & 4.0 \\
\hline $2011-12$ & 4,896 & 849 & 220 & 82.1 & 14.2 & 3.7 \\
\hline $2016-17$ & 5,268 & 891 & 228 & 82.5 & 14.0 & 3.5 \\
\hline
\end{tabular}

Examining the relative percentage of faculty with doctorate, masters and law degrees shows that while the percentage of faculty with a doctorate degree has shown an increase of $10 \%$ over the study period, the proportion of faculty with a master's degree has declined by nearly the same percentage. Figure 1 demonstrates that no significant changes have been made in the relative size of faculty who possess a law degree. 
FIGURE 1

TRENDS IN FACULTY

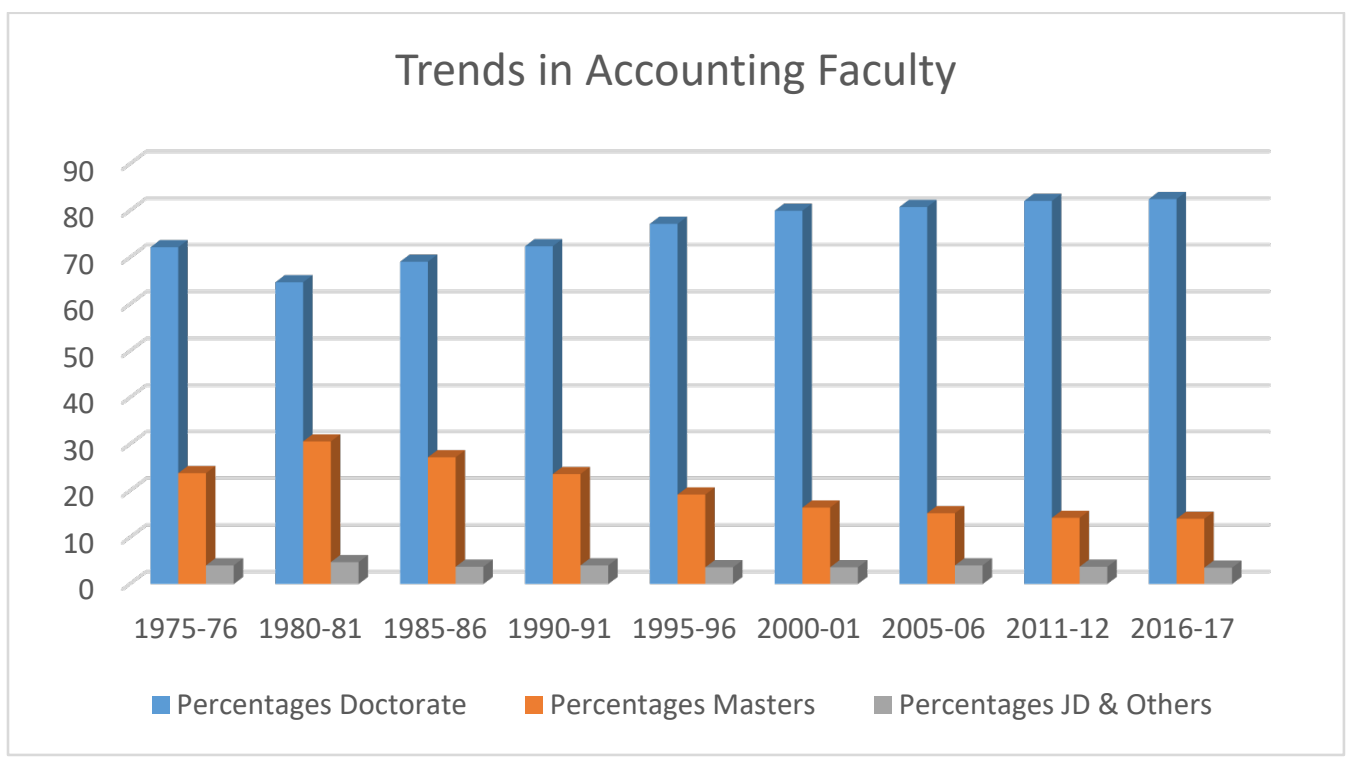

Additionally, our analysis reveals that Hypothesis H1 is easily rejected $(\mathrm{p}<0.00)$ using a paired two sample t test.

To further study the changes experienced in the mix of accounting faculty over the past four decades, we examined the proportions of faculty with certification. Table 2 below contains the percentages of faculty with certificates in CPA, CMA, and or CIA. The data presented in this table reveals that while the number of reported accounting faculty at the U.S. universities

TABLE 2

TRENDS IN ACCOUNTING FACULTY CERTIFICATIONS OVER THE YEARS

\begin{tabular}{|c|c|c|c|c|}
\hline \multirow{2}{*}{$\begin{array}{c}\text { Academic } \\
\text { Years }\end{array}$} & \multicolumn{3}{|c|}{ Percentages } & $\begin{array}{c}\text { Total } \\
\text { Faculty }\end{array}$ \\
\cline { 2 - 4 } & CPA & CMA & CIA & 3,237 \\
\hline $1980-81$ & 77.0 & 4.5 & 0.0 & 4,388 \\
\hline $1985-86$ & 78.1 & 7.0 & 1.2 & 4,972 \\
\hline $1990-91$ & 84.4 & 10.7 & 2.2 & 5,582 \\
\hline $1995-96$ & 80.2 & 11.6 & 3.1 & 5,528 \\
\hline $2000-01$ & 77.9 & 12.3 & 3.3 & 5,693 \\
\hline $2005-06$ & 71.3 & 11.3 & 3.0 & 5,965 \\
\hline $2011-12$ & 66.3 & 9.9 & 2.7 & 6,387 \\
\hline $2016-17$ & 63.1 & 8.9 & 2.7 & \\
\hline
\end{tabular}

Has nearly doubled over the study period, the proportion of those with professional certifications has decreased over the years. The highest percentage of CPAs was reported for the academic year 1990-91 when the percentage of faculty with a CPA certification was at $84.4 \%$. Figure 2 demonstrates trends in number of faculty with certification. 
FIGURE 2

TRENDS IN CERTIFICATIONS

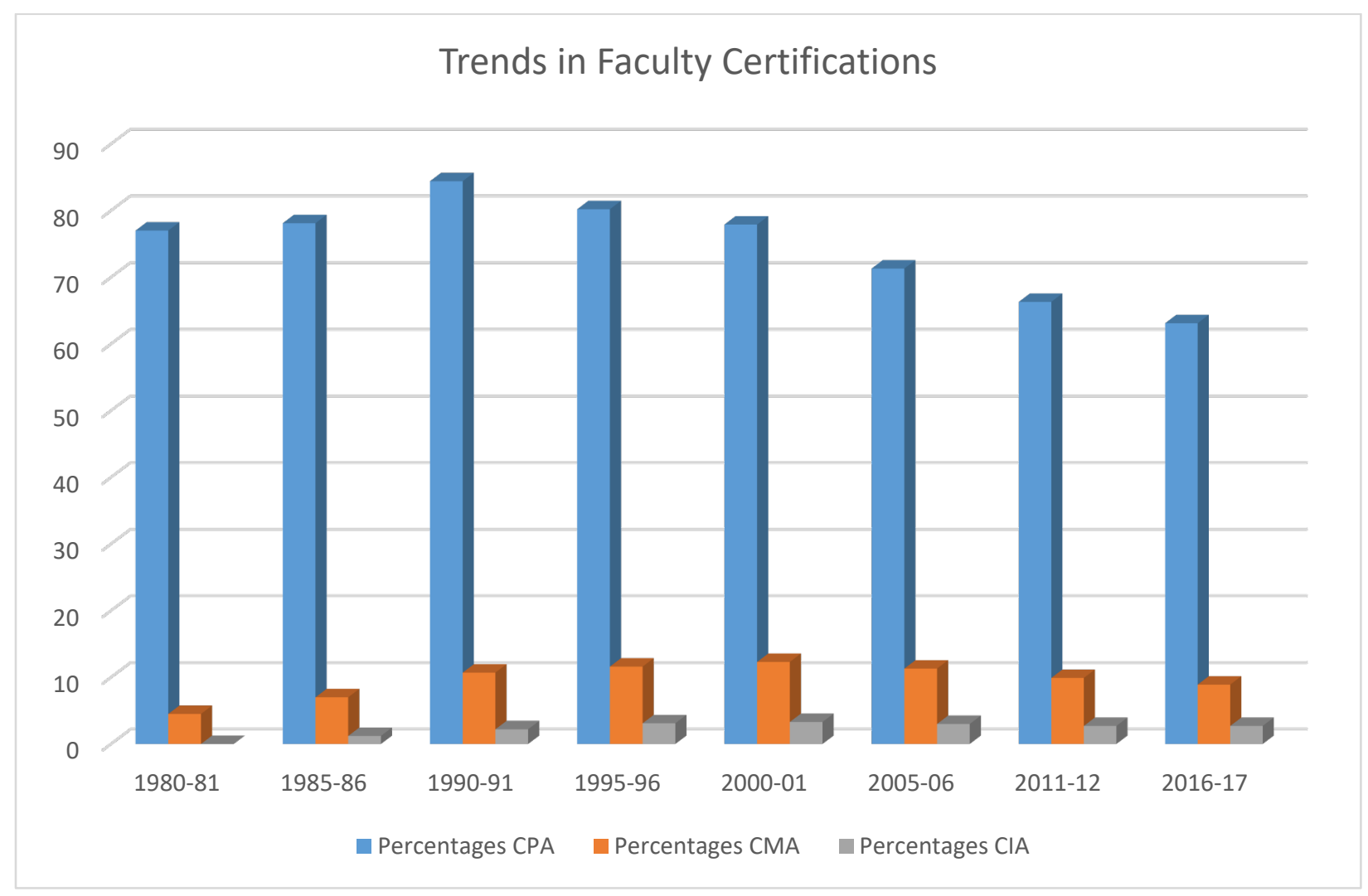

The above graph shows that as the percentage of faculty with CPA certification has declined over the years, the proportion of faculty with the CMA and CIA certification has increased. However, the increase in those with the CMA and CIA certifications combined has not been quite adequate to offset the percentage of decline in the number of CPAs.

Using a paired t-test reveals that Hypothesis $\mathrm{H} 2$ is easily rejected at $\mathrm{p}<0.00$. Thus, the data found in the Hasselback Directories does not provide any evidence corroborating the recommendations made by the Advisory Committee on the Auditing Profession to the U.S. Department of the Treasury or the Pathways Commission.

\section{CONCLUSION}

Accounting education has experienced significant changes since its inception in the United States. The education that started for training bookkeepers soon was expanded to encompass a curriculum designed to prepare auditors and students who pursued CPA designation (Langenderfer, 1987). Colleges and universities across the country started to develop accounting courses and degree programs by hiring practicing accountants. Gradually, with the establishment of business and accounting accrediting standards, AACSB accreditation became a widespread fad among universities across the nation. The results have been hiring of more faculty who are academically qualified and possess doctorate degrees with the potential to pursue research and publications in academic journals. This movement has contributed to a shift in the percentage of faculty who have a practice orientation and those with academic orientation. According to one study, during this period, the faculty holding the Ph.D. or D.B.A. degrees increased by more than $50 \%$ while the number of faculty without a doctorate degree dropped significantly (Gibson and Schroeder, 1998). 
In recent years several groups have suggested that the accounting programs should find ways to attract more practitioners to join the university faculty in order to integrate accounting theory with practice. For example, in a 2008 report by the Advisory Committee on the Auditing Profession to the U.S. Department of the Treasury, commented that many new faculty have little or no practical accounting experience and suggested that bringing more professionals to teach at the university will result in the development of wellprepared entry-level accounting professionals (Advisory Committee, 2008). Later the Pathways Commission also suggested a closer integration of accounting education and research with practice (Pathways Commission, 2012).

This study examined the data gathered by the Hasselback Directories reported over a period of forty years providing information about the mix of accounting faculty. The results showed that contrary to the expectations of the abovementioned groups, both the number and percentage of faculty holding the Ph.D. and D.B.A. degrees have increased year after year. The evidence also demonstrates that during the same period, the proportion of faculty who hold CPA certificates, the most widely known credential for accounting professionals, has shown a steady decline.

There is no doubt that the accounting education must keep pace with the accounting practice. This relationship is even more important now that the face of business is taking drastic changes due to the widespread use of technology and accounting software. With the recent developments, such as data analytics, accountants are now expected to take on a variety of responsibilities they previously did not have. The modern accountants are expected to play the role of business advisors who assist their employers and clients on a variety of topics such as budgeting, financial planning, forecasting, internal controls and decision support.

These changes pose new set of challenges for the universities. To make their graduates marketable, the accounting programs must be willing to hire faculty who have professional skills to teach what they practice in the field. To facilitate this action, AACSB accreditation authorities need to revise business and accounting accrediting standards towards the goal of achieving the Pathways Commission's recommendations.

\section{REFERENCES}

Advisory Committee on the Auditing Profession. (2008, October 1). Final Report of the Advisory Committee on the Auditing Profession to the U.S. Department of the Treasury. Retrieved from https://www.treasury.gov/about/organizational-structure/offices/Documents/final-report.pdf

Albrecht, W.S., \& Sack, R.J. (2000). Accounting Education: Charting the Course through a Perilous Future. Accounting Education Series, 16. Sarasota, FL: American Accounting Association.

American Accounting Association and American Institute of Certified Public Accountants. (2012, July). The Pathways Commission, Charting a National Strategy for the Next Generation of Accountants.

Butler, M.G., Gabriel, E.A., \& Martin, S. (2008, January/February). A CPA is a CPA: Professional Standards and CPAs in Industry (pp. 54-57). Dublin.

Gibson, C., \& Schroeder, N. (1998, Winter). The Changing face of Accounting Faculties. Review of Business, pp. 16-20.

Hasselback, J.R. (2016). Faculty Directories. Retrieved from http://www.jrhasselback.com/FacDir.html

Langenderfer, H.Q. (1987, May). Accounting Education's History-A 100-Year Search for Identity. Journal of Accountancy, pp. 302-331.

Lockwood, J. (1938, June). Early University Education in Accountancy. The Accounting Review, pp. $131-144$.

Wyhe, G.V. (2007, May). A History of U.S. Higher Education in Accounting, Part I: Situating Accounting within the Academy. Issues in Accounting Education, pp. 165-181.

Wyhe, G.V. (2007, August). A History of U.S. Higher Education in Accounting, Part II: Situating Accounting within the Academy. Issues in Accounting Education, pp. 481-501. 